\title{
ARTICLE
}

Cite this: DOI: $10.1039 / \times 0 \times x 00000 x$

Received 00th January 2012, Accepted 00th January 2012

DOI: $10.1039 / \times 0 \times x 00000 x$

www.rsc.org/

\section{Environmental control in the assembly of metallomacrocycles and one-dimensional polymers with 4,2':6':4'-terpyridine linkers and zinc(II) nodes}

\author{
Edwin C. Constable, ${ }^{a}$ Catherine E. Housecroft, ${ }^{* a}$ Alessandro Prescimone, ${ }^{a}$ \\ Srboljub Vujovic ${ }^{a}$ and Jennifer A. Zampese ${ }^{a}$
}

\begin{abstract}
Room temperature crystallization experiments have been carried out by layering to investigate the assemblies produced from combinations of $\mathrm{ZnCl}_{2}$ and 4'-(4-(naphth-1-yl)phenyl)-4,2':6',4"-terpyridine (1) or $4^{\prime}-\left(2^{\prime}, 3^{\prime}, 4^{\prime}, 5^{\prime}, 6^{\prime}\right.$-pentafluorobiphenyl-4-yl)-4, $2^{\prime}: 6^{\prime}, 4^{\prime \prime}$-terpyridine (2) in the presence of the potential inclusion guests anthracene, pyrene or perylene. The reactions lead to the formation of the discrete metallohexacycle $\left[\left\{\mathrm{ZnCl}_{2}(\mathbf{1})\right\}_{6}\right]$ when anthracene or perylene is present, but ${ }^{1} \mathrm{H}$ NMR spectroscopic studies confirm that neither molecule is incorporated as a guest in the lattice. When pyrene is present, a onedimensional coordination polymer $\left[\mathrm{ZnCl}_{2}(\mathbf{1})\right]_{n}$ with a crenellated topology assemblies, and under the same crystallization conditions, a structurally analogous polymer $\left[\mathrm{ZnCl}_{2}(2)\right]_{n}$ can also be isolated. In these structures, pyrene is included as a guest, along with 1,2-dichlorobenzene used as a solvent for the crystallizations. The formation of the polymer $\left[\mathrm{ZnCl}_{2}(2)\right]_{n}$ competes with that of the metallosquare $\left[\left\{\mathrm{ZnCl}_{2}(\mathbf{2})\right\}_{4}\right]$. The metallohexacycles and metallosquare assemble into tube-like arrays, generating highly porous lattices from which solvent loss is facile. In contrast to the topologies of the one-dimensional chains in $\left[\mathrm{ZnCl}_{2}(\mathbf{1})\right]_{n}$ and $\left[\mathrm{ZnCl}_{2}(\mathbf{2})\right]_{n}$, the one-dimensional coordination polymer $\left[\mathrm{ZnI}_{2}(\mathbf{1})\right]_{n}$ is built up along a glide plane; stacking of the chains through head-to-tail pairings of ligands produces corrugated sheets which pack efficiently in the lattice.
\end{abstract}

\section{Introduction}

$4,2^{\prime}: 6^{\prime}, 4^{\prime \prime}-$ Terpyridine $\left(4,2^{\prime}: 6^{\prime}, 4^{\prime \prime}\right.$-tpy) ligands are increasingly popular as building blocks for the assembly of coordination polymers. ${ }^{1}$ Easily functionalized in the $4^{\prime}$-position, ${ }^{2} 4,2^{\prime}: 6^{\prime}, 4^{\prime \prime}-$ tpy domains have significant potential for determining the outcome of the self-assembly processes. Reactions between zinc(II) halides and 4'-X-4,2':6',4"-tpy ligands typically yield one-dimensional polymers. Exceptions may (but do not always $)^{3}$ arise when the substituent $X$ has additional coordination capacity. For example, when $\mathrm{X}=4$-pyridyl, a closed metallocapsule is obtained, ${ }^{4,5}$ and when $\mathrm{X}=\mathrm{CO}_{2} \mathrm{H}$, twoor three-dimensional networks may form. ${ }^{6,7,8}$ Assemblies containing zinc(II) nodes can also be variously directed by the introduction of co-ligands. ${ }^{8,9}$ Interconnection of two 4,2':6',4"tpy metal-binding domains in a ditopic ligand leads to twodimensional networks; the reaction of 1,4-bis(n-octyloxy)-2,5bis(4,2':6',4"-terpyridin-4'-yl)benzene with $\mathrm{ZnCl}_{2}$ yields corrugated two-dimensional $(4,4)$ nets which interpenetrate in a $2 \mathrm{D} \rightarrow 2 \mathrm{D}$ parallel manner. ${ }^{10}$

We have previously reported the syntheses of ligands $\mathbf{1}^{11}$ and $\mathbf{2}^{12}$ (Scheme 1) which possess extended arene systems, and we have observed that reactions of $\mathrm{Cu}(\mathrm{OAc})_{2} \mathrm{H}_{2} \mathrm{O}$ with 2 or its phenyl analogue 3 (Scheme 1) give isostructural polymers $\left[\mathrm{Cu}_{2}(\mathrm{OAc})_{4}(\mathrm{~L})\right]_{n}$ with $\mathrm{L}=\mathbf{1}$ or $\mathbf{2},{ }^{12}$ indicating that the perfluorosubstituent exerts little influence over the assembly process. On the other hand, when 2 reacts with $\mathrm{Zn}(\mathrm{OAc})_{2} 2 \mathrm{H}_{2} \mathrm{O}$, both $\left[\mathrm{Zn}_{2}(\mathrm{OAc})_{4}(\mathbf{2})\right]_{n}$ and $\left[\mathrm{Zn}_{5}(\mathrm{OAc})_{10}(2)_{4} \cdot 11 \mathrm{H}_{2} \mathrm{O}\right]_{n}$ crystallize from the same reaction mixture, a result that we can only explain in terms of serendipity. ${ }^{12}$

Metallohexacycles $\quad\left[\left\{\mathrm{ZnCl}_{2}\left(4^{\prime}-\mathrm{X}-4,2^{\prime}: 6^{\prime}, 4^{\prime \prime} \text {-tpy }\right)\right\}_{6}\right] \quad$ or [ $\left.\left\{\mathrm{ZnBr}_{2}\left(4^{\prime}-\mathrm{X}-4,2^{\prime}: 6^{\prime}, 4^{\prime \prime}-\text { tpy }\right)\right\}_{6}\right]$ are persistent, albeit unexpected, motifs obtained in reactions between $\mathrm{ZnCl}_{2}$ or $\mathrm{ZnBr}_{2}$ and $4^{\prime}-\mathrm{X}$ $4,2^{\prime}: 6^{\prime}, 4^{\prime \prime}$-tpy ligands. We originally observed this phenomenon with $\left[\left\{\mathrm{ZnCl}_{2}\left(4^{\prime}-\mathrm{HC} \equiv \mathrm{CC}_{6} \mathrm{H}_{4}-4,2^{\prime}: 6^{\prime}, 4^{\prime \prime}-\text { tpy }\right)\right\}_{6}\right]^{13}$ but later noted that the presence of an extended aromatic domain appeared to be important in favouring the assembly of a metallohexacycle over a polymer. ${ }^{14}$ Several features of the metallohexacyclic arrays are of interest. Two conformers of metallohexacycle are observed: chair-like and barrel-like. Irrespective of conformation, in the solid state, hexamers nestle inside one another, forming infinite nanotubes supported by intermolecular face-to-face $\pi$-interactions. The large void space in the tubes makes these assemblies ideal targets for host-guest chemistry as illustrated by the capture of $\mathrm{C}_{60}{ }^{14}$ The face-to-face stacking interactions between the pendant naphthyl domains in 
1 and $\mathrm{C}_{60}$ are important in the assembly of $\left[2\left\{\mathrm{ZnCl}_{2}(\mathbf{1})\right\}_{6} \mathrm{C}_{60}\right]^{\cdot} 6 \mathrm{MeOH} \cdot 16 \mathrm{H}_{2} \mathrm{O} .{ }^{14}$ The presence of significant numbers of solvent molecules in the lattice confirms a large void space.

We now describe the results of a series of room temperature crystallization experiments in which reactions between $\mathrm{ZnCl}_{2}$ and 1 or $\mathbf{2}$ were carried out in the presence of anthracene, pyrene or perylene in the hope of using host-guest interactions to direct the assembly process. The results reveal the formation of both one-dimensional coordination polymers and discrete $[4+4]$ and [6+6] metallocycles. We have also investigated the consequence of replacing $\mathrm{ZnCl}_{2}$ with $\mathrm{ZnI}_{2}$ in reactions with 1 .
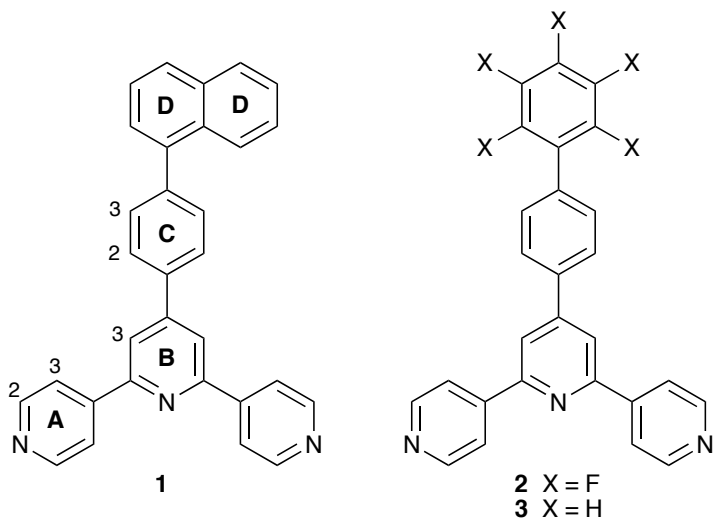

Scheme 1. Structures of ligands $\mathbf{1}, \mathbf{2}$ and $\mathbf{3}$. Proton numbering in $\mathbf{1}$ is for ${ }^{1} \mathrm{H}$ NMR assignments (see Figs. S1 and S2+).

\section{Experimental}

\section{General}

Compounds 1 and 2 were prepared as reported. ${ }^{11,12}$ Anhydrous $\mathrm{ZnCl}_{2}$ and $\mathrm{ZnBr}_{2}$ (Sigma Aldrich) were used as received.

\section{$\left[\left\{\mathrm{ZnCl}_{2}(\mathbf{1})\right\}_{6}\right]-\mathrm{A}$}

Compound 1 (21.8 mg, $0.0500 \mathrm{mmol})$ was dissolved in a mixture of 1,2-dichlorobenzene $(6 \mathrm{~mL})$ and $\mathrm{MeOH}(2 \mathrm{~mL})$ in a long test tube. A solution of anthracene $(36 \mathrm{mg}, 0.20 \mathrm{mmol})$ in 1,2-dichlorobenzene $(2 \mathrm{~mL})$ was added and then a 1,2dichlorobenzene and $\mathrm{MeOH}$ mixture $(3.0 \mathrm{~mL}$ of each) was layered on top. Finally, a solution of $\mathrm{ZnCl}_{2}(6.7 \mathrm{mg}, 0.049$ $\mathrm{mmol})$ in $\mathrm{MeOH}(8.0 \mathrm{~mL})$ was added carefully, and the tube was sealed with Parafilm ' $M$ '. After a month at room temperature, colourless crystals had formed. Yield: $6.8 \mathrm{mg}$, $24 \%$. Found $\mathrm{C} 62.75, \mathrm{H} 3.74, \mathrm{~N} 6.59 ; \mathrm{C}_{31} \mathrm{H}_{21} \mathrm{Cl}_{2} \mathrm{~N}_{3} \mathrm{Zn} . \mathrm{H}_{2} \mathrm{O}$ requires $\mathrm{C} 63.13, \mathrm{H} 3.93, \mathrm{~N} 7.23 \%$.

\section{$\left[\left\{\mathrm{ZnCl}_{2}(\mathbf{1})\right\}_{6}\right]-\mathrm{P}$}

The reaction scale and conditions were as for $\left[\left\{\mathrm{ZnCl}_{2}(\mathbf{1})\right\}_{6}\right]-\mathrm{A}$, replacing anthracene by perylene $(50.5 \mathrm{mg}, 0.2 \mathrm{mmol})$. After a month at room temperature, yellow crystals had formed. Yield: $11.7 \mathrm{mg}, 40.9 \%$. Found 63.81, H 3.95, N 7.09; $\left[\left\{\mathrm{ZnCl}_{2}(\mathbf{1})\right\}_{6}\right] \cdot \mathrm{H}_{2} \mathrm{O}$ requires $\mathrm{C} 63.13, \mathrm{H} 3.93, \mathrm{~N} 7.12 \%$.

\section{$\left[\mathrm{ZnCl}_{\mathbf{2}}(\mathbf{1})\right]_{n}$}

Compound $\mathbf{1}$ (21.8 mg, $0.050 \mathrm{mmol})$ was dissolved in a mixture of 1,2-dichlorobenzene ( $6 \mathrm{~mL})$ and $\mathrm{MeOH}(2 \mathrm{~mL})$ in a long test tube. A solution of pyrene $(41.3 \mathrm{mg}, 0.204 \mathrm{mmol})$ in $1,2-$ dichlorobenzene $(2 \mathrm{~mL})$ was added, followed by a mixture of 1,2-dichlorobenzene $(2.5 \mathrm{~mL})$ and $\mathrm{MeOH}(2.5 \mathrm{~mL})$. A solution of $\mathrm{ZnCl}_{2}(6.7 \mathrm{mg}, 0.049 \mathrm{mmol})$ in $\mathrm{MeOH}(8.0 \mathrm{~mL})$ was then added carefully. The tube was sealed with Parafilm 'M' and left to stand at room temperature. Colourless crystals grew over a period of about a month. Yield: $8.1 \mathrm{mg}, 28 \%$. Found $\mathrm{C} 64.75, \mathrm{H}$ 3.93, N 6.76; $\mathrm{C}_{31} \mathrm{H}_{21} \mathrm{Cl}_{2} \mathrm{~N}_{3} \mathrm{Zn}$ requires $\mathrm{C} 65.12, \mathrm{H} 3.70, \mathrm{~N}$ $7.35 \%$.

\section{$\left[\mathrm{ZnCl}_{2}(2)\right]_{n}$ and $\left[\left\{\mathrm{ZnCl}_{2}(2)\right\}_{4}\right]$}

Compound 2 (23.6 mg, $0.050 \mathrm{mmol})$ was dissolved in a mixture of 1,2-dichlorobenzene (6 mL) and $\mathrm{MeOH}(2 \mathrm{~mL})$ in a long test tube. A solution of pyrene $(41.3 \mathrm{mg}, 0.204 \mathrm{mmol})$ in $1,2-$ dichlorobenzene $(2 \mathrm{~mL})$ was layered on top, followed by a mixture of 1,2-dichlorobenzene $(2.5 \mathrm{~mL})$ and $\mathrm{MeOH}(2.5 \mathrm{~mL})$, and then a solution of $\mathrm{ZnCl}_{2}(6.7 \mathrm{mg}, 0.049 \mathrm{mmol})$ in $\mathrm{MeOH}$ $(8.0 \mathrm{~mL})$. The tube was sealed with Parafilm ' $\mathrm{M}$ ' and over a period of a month at room temperature, colourless crystals grew. Satisfactory elemental analysis for the bulk sample was not obtained.

\section{$\left[\mathrm{ZnI}_{\mathbf{2}}(\mathbf{1})\right]_{n}$}

A solution of $1(21.8 \mathrm{mg}, 0.050 \mathrm{mmol})$ in $\mathrm{CHCl}_{3}(6.0 \mathrm{~mL})$ was placed in a long test tube, and $\mathrm{MeOH}(3.0 \mathrm{~mL})$ was layered on top, followed by a solution of $\mathrm{ZnI}_{2}(15.8 \mathrm{mg}, 0.0495 \mathrm{mmol})$ in $\mathrm{MeOH}(5.0 \mathrm{~mL})$. The tube was sealed with Parafilm 'M' and was left at room temperature. Over a period of a week, yellowish crystals grew. Yield: $(18.1 \mathrm{mg}, 47.7 \%)$. Found C 43.20, H 3.09, N 4.70; $\mathrm{C}_{31} \mathrm{H}_{21} \mathrm{I}_{2} \mathrm{~N}_{3} \mathrm{Zn}$. $\mathrm{CHCl}_{3}$ requires $\mathrm{C} 43.97$, H $2.54, \mathrm{~N} 4.81 \%$.

\section{Crystallography}

Data were collected on a Bruker-Nonius Kappa APEX diffractometer; data reduction, solution and refinement used APEX2 ${ }^{15}$ with SHELX13. ${ }^{16}$ The ORTEP plot was produced with Mercury v. 3.3 $3^{17,18}$ which was also used for structure analysis. Except for crystals of $\left[2\left\{\mathrm{ZnI}_{2}(\mathbf{1})\right\} \mathrm{CHCl}_{3}\right]_{n}$, rapid solvent loss influenced data quality and for these structures, the program SQUEEZE ${ }^{19}$ was used to treat the data. Relatively poor quality structural data in some cases is due to weak high angle reflections and poor diffraction related to large cell volumes, extreme solvent disorder and solvent loss.

\section{$\left[\left\{\mathrm{ZnCl}_{2}(\mathbf{1})\right\}_{6}\right]^{\cdot} \mathbf{3 \mathrm { C } _ { 6 }} \mathrm{H}_{\mathbf{4}} \mathrm{Cl}_{\mathbf{2}} \cdot \mathbf{6} \mathrm{MeOH}=\left[\left\{\mathrm{ZnCl}_{2}(\mathbf{1})\right\}_{6}\right]-\mathrm{A}$}

After SQUEEZE and with modelled solvent: $\mathrm{C}_{210} \mathrm{H}_{146} \mathrm{Cl}_{18} \mathrm{~N}_{18} \mathrm{O}_{6} \mathrm{Zn}_{6}, M=4064.14$, colourless block, trigonal, space group $R-3, a=b=35.744(2), c=23.9081(16) \AA, U=$ 26453(4) $\AA^{3}, Z=3, D_{c}=0.765 \mathrm{Mg} \mathrm{m}^{-3}, \mu(\mathrm{Cu}-\mathrm{K \alpha} \alpha)=1.503$ $\mathrm{mm}^{-1}, T=123 \mathrm{~K}$. Total 49363 reflections, 10603 unique, $R_{\text {int }}=$ 0.0765 . Refinement of 6980 reflections (334 parameters) with $I$ $>2 \sigma(I)$ converged at final $R 1=0.0311(R 1$ all data $=0.0526)$, 
$w R 2=0.0626(w R 2$ all data $=0.0661)$, gof $=0.799 . \mathrm{CCDC}$ 992575.

\section{$\left[\left\{\mathrm{ZnCl}_{2}(1)\right\}_{6} \mid \cdot 3 \mathrm{C}_{6} \mathrm{H}_{4} \mathrm{Cl}_{2} \cdot \mathbf{2} \mathrm{MeOH}=\left[\left\{\mathrm{ZnCl}_{2}(1)\right\}_{6}\right]-\mathrm{P}\right.$}

After SQUEEZE and with modelled solvent: $\mathrm{C}_{206} \mathrm{H}_{146} \mathrm{Cl}_{18} \mathrm{~N}_{18} \mathrm{O}_{2} \mathrm{Zn}_{6}, M=3959.99$, yellow block, trigonal, space group $R-3, a=b=70.6015(18), c=23.9920(6) \AA, U=$ $103568(6) \AA^{3}, Z=12, D_{c}=0.762 \mathrm{Mg} \mathrm{m}^{-3}, \mu(\mathrm{Cu}-\mathrm{K \alpha})=1.536$ $\mathrm{mm}^{-1}, T=123 \mathrm{~K}$. Total 207036 reflections, 42281 unique, $R_{\text {int }}$ $=0.1874$. Refinement of 20632 reflections (1339 parameters) with $I>2 \sigma(I)$ converged at final $R 1=0.1199(R 1$ all data $=$ $0.1790), w R 2=0.2869(w R 2$ all data $=0.3228)$, gof $=0.971$. CCDC 992580.

\section{$\left[\mathrm{ZnCl}_{\mathbf{2}}(\mathbf{1})\right]_{n}$}

After SQUEEZE: $\mathrm{C}_{124} \mathrm{H}_{84} \mathrm{Cl}_{8} \mathrm{~N}_{12} \mathrm{Zn}_{4}, M=2287.20$, colourless block, triclinic, space group $P-1, a=14.3701(12), b=$ 22.089(2), $c=26.512(3) \AA, \alpha=95.414(6), \beta=95.480(6), \gamma=$ 92.935(5), $U=8324.2(13) \AA^{3}, Z=2, D_{c}=0.912 \mathrm{Mg} \mathrm{m}^{-3}, \mu(\mathrm{Cu}-$ $\mathrm{K} \alpha)=2.123 \mathrm{~mm}^{-1}, T=123 \mathrm{~K}$. Total 76749 reflections, 29093 unique, $R_{\text {int }}=0.0600$. Refinement of 19792 reflections (1333 parameters) with $I>2 \sigma(I)$ converged at final $R 1=0.0714(R 1$ all data $=0.0941), w R 2=0.1933(w R 2$ all data $=0.2079)$, gof $=$ 1.034. CCDC 1006953.

\section{$\left[\mathrm{ZnCl}_{\mathbf{2}}(\mathbf{2})\right]_{n}$}

After SQUEEZE: $\mathrm{C}_{108} \mathrm{H}_{56} \mathrm{Cl}_{8} \mathrm{~F}_{20} \mathrm{~N}_{12} \mathrm{Zn}_{4}, \quad M=2446.81$, colourless plate, triclinic, space group $P-1, a=14.3665(6), b=$ 20.7814(8), $c=26.2162(13) \AA, \alpha=99.654(3), \beta=97.510(3)$, $\gamma=103.905(3), U=7369.5(6) \AA^{3}, Z=2, D_{c}=1.103 \mathrm{Mg} \mathrm{m}^{-3}$, $\mu(\mathrm{Cu}-\mathrm{K} \alpha)=2.629 \mathrm{~mm}^{-1}, T=123 \mathrm{~K}$. Total 57651 reflections, 25727 unique, $R_{\text {int }}=0.0583$. Refinement of 16085 reflections (1369 parameters) with $I>2 \sigma(I)$ converged at final $R 1=$ $0.0695(R 1$ all data $=0.1002), w R 2=0.1763(w R 2$ all data $=$ 0.1906), gof $=0.932$. CCDC 1006954 .

\section{$\left[\left\{\mathrm{ZnCl}_{2}(2)\right\}_{4}\right]^{\cdot} 2 \mathrm{C}_{6} \mathrm{H}_{4} \mathrm{Cl}_{2} .5 \mathrm{MeOH}$}

After SQUEEZE and with modelled solvent: $\mathrm{C}_{125} \mathrm{H}_{85} \mathrm{Cl}_{12} \mathrm{~F}_{20} \mathrm{~N}_{12} \mathrm{O}_{5} \mathrm{Zn}_{4}, \quad M=2901.04$, colourless plate, tetragonal, space group $P-42{ }_{1} c, a=b=23.6145(15), c=$ 16.4568(10) $\AA, U=177.0(13) \AA^{3}, Z=2, D_{c}=1.050 \mathrm{Mg} \mathrm{m}^{-3}$, $\mu(\mathrm{Cu}-\mathrm{K} \alpha)=2.111 \mathrm{~mm}^{-1}, T=123 \mathrm{~K}$. Total 75018 reflections, 8428 unique, $R_{\text {int }}=0.2237$. Refinement of 3283 reflections ( 344 parameters) with $I>2 \sigma(I)$ converged at final $R 1=0.0769(R 1$ all data $=0.1907), w R 2=0.1590(w R 2$ all data $=0.1884)$, gof $=$ 0.853. CCDC 992577.

\section{$\left[2\left\{\mathrm{ZnI}_{2}(1)\right\} \cdot \mathrm{CHCl}_{3}\right]_{n}$}

$\mathrm{C}_{63} \mathrm{H}_{43} \mathrm{Cl}_{3} \mathrm{I}_{4} \mathrm{~N}_{6} \mathrm{Zn}_{2}, M=1628.76$, colourless plate, monoclinic, space group $P 2_{1} / c, a=14.9652(10), b=16.3097(12), c=$ 24.4444(18) $\AA, \beta=91.698(2)^{\circ}, U=5963.7(7) \AA^{3}, Z=4, D_{c}=$ $1.814 \mathrm{Mg} \mathrm{m}^{-3}, \mu(\mathrm{Cu}-\mathrm{K} \alpha)=3.055 \mathrm{~mm}^{-1}, T=123 \mathrm{~K}$. Total 86490 reflections, 11089 unique, $R_{\mathrm{int}}=0.0766$. Refinement of 8572 reflections (741 parameters) with $I>2 \sigma(I)$ converged at final $R 1=0.0493(R 1$ all data $=0.0728), w R 2=0.1034(w R 2$ all data $=0.1195)$, gof $=1.138$. CCDC 992579 .

\section{Results and discussion}

\section{Reaction of 1 with $\mathrm{ZnCl}_{2}$ in the presence of anthracene or} perylene

We have shown ${ }^{14}$ that crystal growth by layering $1 / \mathrm{CHCl}_{3}$ with $\mathrm{ZnX}_{2} / \mathrm{MeOH} \quad(\mathrm{X}=\mathrm{Cl}, \mathrm{Br})$ leads to cyclic hexamers $\left[\left\{\mathrm{ZnX}_{2}(\mathbf{1})\right\}_{6}\right]$. Using analogous room temperature conditions, crystallizations were repeated using layers of 1/1,2dichlorobenzene and $\mathrm{ZnCl}_{2} / \mathrm{MeOH}$ with an intermediate layer of anthracene or perylene/1,2-dichlorobenzene. Crystals grew over a period of a month as the solvents slowly diffused but, once removed from the mother liquor, the crystals were extremely difficult to handle due to solvent loss. This was reminiscent of the properties of crystalline $\left[\left\{\mathrm{ZnX}_{2}(\mathbf{1})\right\}_{6}\right] .{ }^{14}$ Structure solutions were performed using SQUEEZE ${ }^{19}$ to treat the data. For convenience, we label the complexes $\left[\left\{\mathrm{ZnCl}_{2}(\mathbf{1})\right\}_{6}\right]-\mathrm{A}$ and $\left[\left\{\mathrm{ZnCl}_{2}(\mathbf{1})\right\}_{6}\right]-\mathrm{P}$ for the anthracene and perylene-derived species, noting that this does not imply the presence of these aromatic molecules in the lattice. The SQUEEZED electron density was modelled as a combination of $1,2-\mathrm{C}_{6} \mathrm{H}_{4} \mathrm{Cl}_{2}$ and $\mathrm{MeOH}$ molecules (see experimental section). In order to provide support for the presence of 1,2dichlorobenzene in the lattice, single crystals of $\left[\left\{\mathrm{ZnCl}_{2}(\mathbf{1})\right\}_{6}\right]-$ A were dissolved in DMF- $\mathrm{d}_{7}$ and the ${ }^{1} \mathrm{H}$ NMR spectrum recorded (Fig. S1 $\dagger$ ). The data confirm the presence of 1,2$\mathrm{C}_{6} \mathrm{H}_{4} \mathrm{Cl}_{2}$ and the absence of guest anthracene molecules. The ${ }^{1} \mathrm{H}$ NMR spectrum of a DMF- $\mathrm{d}_{7}$ solution of $\left[\left\{\mathrm{ZnCl}_{2}(\mathbf{1})\right\}_{6}\right]-\mathrm{P}$ was also recorded. The spectra shown in Fig. $\mathrm{S} 2 \uparrow$ indicate that crystals of $\left[\left\{\mathrm{ZnCl}_{2}(\mathbf{1})\right\}_{6}\right]-\mathrm{P}$ contain $1,2-\mathrm{C}_{6} \mathrm{H}_{4} \mathrm{Cl}_{2}$, but no perylene. These results are consistent with the modelling of the SQUEEZED electron density. The similarity between the ${ }^{1} \mathrm{H}$ NMR spectra of dissolved complex and free ligand 1 suggest that the complexes dissociate in solution. However, we note that the data are not unambiguous since the small shift in the signal $\approx \partial 8.5 \mathrm{ppm}$ (assigned to proton $\mathrm{H}^{\mathrm{A} 3}$, see Scheme 1) may be indicative of coordination of the outer pyridine ring to zinc(II).

The products from both the anthracene- or perylenecontaining systems crystallized in the space group $R-3$ and, after SQUEEZE, had identical formulations of $\left[\left\{\mathrm{ZnCl}_{2}(\mathbf{1})\right\}_{6}\right]$ and both lattices contain discrete metallohexacycles analogous to those previously described. ${ }^{14}$ The lattice parameters of the two compounds differ (see experimental section), with the $a$ and $b$-axes doubling from $\left[\left\{\mathrm{ZnCl}_{2}(\mathbf{1})\right\}_{6}\right]-\mathrm{A}$ to $\left[\left\{\mathrm{ZnCl}_{2}(\mathbf{1})\right\}_{6}\right]-\mathrm{P}$ while the $c$-axis remains approximately constant. We return to this observation later.

The asymmetric unit in $\left[\left\{\mathrm{ZnCl}_{2}(\mathbf{1})\right\}_{6}\right]-\mathrm{A}$ contains one $\left\{\mathrm{ZnCl}_{2}(\mathbf{1})\right\}$ unit and the molecule shown in Fig. 1a is generated by a 3 -fold rotoinversion, yielding $\left[\left\{\mathrm{ZnCl}_{2}(\mathbf{1})\right\}_{6}\right]$ in a barrel-like conformation. The asymmetric unit in $\left[\left\{\mathrm{ZnCl}_{2}(\mathbf{1})\right\}_{6}\right]$-P contains one $\left\{\mathrm{ZnCl}_{2}(\mathbf{1})\right\}$ unit and one $\left\{\mathrm{Zn}_{3} \mathrm{Cl}_{6}(\mathbf{1})_{3}\right\}$ unit, defining two independent $\left[\left\{\mathrm{ZnCl}_{2}(\mathbf{1})\right\}_{6}\right]$ molecules generated by 3 -fold rotoinversion (Fig. 1b) or inversion (Fig. 1c), respectively. It follows that the lattice contains three times as many of the latter than the former; we return to this in the discussion of packing. 
Both possess the same conformation as $\left[\left\{\mathrm{ZnCl}_{2}(\mathbf{1})\right\}_{6}\right]$-A. Table 1 gives pertinent bond parameters; atom labelling is defined in Fig. 1. Bond lengths and angles in the coordination spheres of the zinc(II) centres are unexceptional. The structures shown in Figs. $1 \mathrm{a}$ and $1 \mathrm{~b}$ are very similar, and values of the cross-ring separations Zn1...Zn1ii (Fig. 1a) and Zn10...Zn10ii (Fig. 1b) of 24.781(1) and 24.514(2) $\AA$ confirm this. The second independent molecule of $\left[\left\{\mathrm{ZnCl}_{2}(\mathbf{1})\right\}_{6}\right]-\mathrm{P}$ is noticeably flattened with $\mathrm{Zn} 1 \ldots \mathrm{Zn} 1^{\mathrm{i}}$ and $\mathrm{Zn} 2 \ldots \mathrm{Zn} 2^{\mathrm{i}}$ separations of $24.495(2)$ and 26.497(2) Å.

Table 1. Comparison of selected structural data for $\left[\left\{\mathrm{ZnCl}_{2}(\mathbf{1})\right\}_{6}\right]-\mathrm{A}$ and $\left[\left\{\mathrm{ZnCl}_{2}(\mathbf{1})\right\}_{6}\right]-\mathrm{P}$; bond distances in $\AA$, and angles in deg.

\begin{tabular}{|c|c|c|c|}
\hline \multicolumn{4}{|c|}{$\left[\left\{\mathrm{ZnCl}_{2}(\mathbf{1})\right\}_{6}\right]-\mathrm{A}$ (Fig. 1a) } \\
\hline Zn1-Cl1 & $2.2140(5)$ & $\mathrm{Zn} 1-\mathrm{Cl} 2$ & $2.2204(5)$ \\
\hline Zn1-N1 & $2.0391(13)$ & $\mathrm{Zn} 1-\mathrm{N} 3^{\mathrm{i}}$ & $2.0510(13)$ \\
\hline $\mathrm{Cl} 1-\mathrm{Zn} 1-\mathrm{Cl} 2$ & $126.27(2)$ & $\mathrm{N} 1-\mathrm{Zn} 1-\mathrm{Cl1}$ & $107.24(4)$ \\
\hline $\mathrm{N} 1-\mathrm{Zn} 1-\mathrm{N} 3^{\mathrm{i}}$ & $103.10(6)$ & $\mathrm{N} 3^{\mathrm{i}}-\mathrm{Zn} 1-\mathrm{Cl} 1$ & $104.52(4)$ \\
\hline $\mathrm{N} 1-\mathrm{Zn} 1-\mathrm{Cl} 2$ & $105.78(4)$ & $\mathrm{N} 3^{\mathrm{i}}-\mathrm{Zn} 1-\mathrm{Cl} 2$ & $107.74(4)$ \\
\hline $\mathrm{Zn} 1 \ldots \mathrm{Zn} 1^{\mathrm{ii}}$ & $24.781(1)$ & & \\
\hline \multicolumn{4}{|c|}{$\left[\left\{\mathrm{ZnCl}_{2}(\mathbf{1})\right\}_{6}\right]-\mathrm{P}$ independent molecule 1 (Fig. 1b) } \\
\hline $\mathrm{Zn} 10-\mathrm{Cl} 10$ & $2.2285(15)$ & Zn10-Cl11 & $2.2333(14)$ \\
\hline Zn10-N101 & $2.031(5)$ & $\mathrm{Zn} 10-\mathrm{N} 103^{\mathrm{i}}$ & $2.071(4)$ \\
\hline $\mathrm{Cl10}-\mathrm{Zn} 10-\mathrm{Cl11}$ & $124.65(6)$ & N101-Zn10-C110 & $105.67(13)$ \\
\hline $\mathrm{N} 101-\mathrm{Zn} 10-\mathrm{N} 103^{\mathrm{i}}$ & $101.85(17)$ & $\mathrm{N} 103^{\mathrm{i}}-\mathrm{Zn} 10-\mathrm{Cl} 10$ & $102.59(13)$ \\
\hline N101-Zn10-Cl11 & $110.13(12)$ & $\mathrm{N} 103^{1}-\mathrm{Zn} 10-\mathrm{Cl} 11$ & $109.49(12)$ \\
\hline $\mathrm{Zn} 10 \ldots \mathrm{Zn} 10^{\mathrm{ii}}$ & $24.514(2)$ & & \\
\hline \multicolumn{4}{|c|}{$\left[\left\{\mathrm{ZnCl}_{2}(\mathbf{1})\right\}_{6}\right]-\mathrm{P}$ independent molecule 2 (Fig. 1c) } \\
\hline Zn1-Cl1 & $2.2107(15)$ & $\mathrm{Zn} 1-\mathrm{Cl} 2$ & $2.2161(13)$ \\
\hline Zn1-N1 & $2.064(3)$ & $\mathrm{Zn} 1-\mathrm{N} 9^{\mathrm{i}}$ & $2.038(4)$ \\
\hline $\mathrm{Cl} 1-\mathrm{Zn} 1-\mathrm{Cl} 2$ & $125.59(6)$ & $\mathrm{N} 1-\mathrm{Zn} 1-\mathrm{Cl1}$ & $107.93(12)$ \\
\hline $\mathrm{N} 9 \mathrm{i}-\mathrm{Zn} 1-\mathrm{N} 1$ & $99.71(16)$ & N9 ${ }^{\mathrm{Z}} \mathrm{Zn} 1 \mathrm{Cl1}$ & $109.56(12)$ \\
\hline $\mathrm{N} 1-\mathrm{Zn} 1-\mathrm{Cl} 2$ & $106.60(10)$ & $\mathrm{N} 9^{-}-\mathrm{Zn} 1-\mathrm{Cl} 2$ & $104.43(11)$ \\
\hline $\mathrm{Zn} 2-\mathrm{Cl} 3$ & $2.2384(14)$ & $\mathrm{Zn} 2-\mathrm{Cl} 4$ & $2.2276(12)$ \\
\hline $\mathrm{Zn} 2-\mathrm{N} 4$ & $2.028(5)$ & Zn2-N3 & $2.030(4)$ \\
\hline $\mathrm{Cl} 4-\mathrm{Zn} 2-\mathrm{Cl} 3$ & 126.61(6) & N4-Zn2-N3 & $102.51(18)$ \\
\hline $\mathrm{N} 4-\mathrm{Zn} 2-\mathrm{Cl} 4$ & $106.43(11)$ & $\mathrm{N} 3-\mathrm{Zn} 2-\mathrm{Cl} 3$ & $102.05(13)$ \\
\hline $\mathrm{N} 4-\mathrm{Zn} 2-\mathrm{Cl} 3$ & $108.66(12)$ & $\mathrm{N} 3-\mathrm{Zn} 2-\mathrm{Cl} 4$ & $108.10(11)$ \\
\hline $\mathrm{Zn} 3-\mathrm{Cl} 5$ & $2.2243(14)$ & $\mathrm{Zn} 3-\mathrm{Cl} 6$ & $2.2385(15)$ \\
\hline Zn3-N7 & $1.995(4)$ & Zn3-N6 & $2.027(4)$ \\
\hline $\mathrm{Cl} 5-\mathrm{Zn} 3-\mathrm{Cl} 6$ & $123.77(5)$ & N6-Zn3-Cl6 & $104.18(14)$ \\
\hline N7-Zn3-N6 & $106.30(16)$ & N7-Zn3-Cl5 & $106.50(13)$ \\
\hline N6-Zn3-Cl5 & $107.23(12)$ & $\mathrm{N} 7-\mathrm{Zn} 3-\mathrm{Cl} 6$ & $107.74(12)$ \\
\hline $\mathrm{Zn} 1 \ldots \mathrm{Zn} 1^{\mathrm{i}}$ & $24.495(2)$ & $\mathrm{Zn} 2 \ldots \mathrm{Zn} 2^{\mathrm{i}}$ & $26.497(2)$ \\
\hline
\end{tabular}

Cell parameters for $\left[\left\{\mathrm{ZnCl}_{2}(\mathbf{1})\right\}_{6}\right]-\mathrm{A}, \quad\left[\left\{\mathrm{ZnCl}_{2}(\mathbf{1})\right\}_{6}\right]-\mathrm{P}$, $\left[\left\{\mathrm{ZnBr}_{2}(\mathbf{1})\right\}_{6}\right] \cdot 3 \mathrm{CHCl}_{3} \cdot 15 \mathrm{H}_{2} \mathrm{O}$ and the host-guest complex $\left[2\left\{\mathrm{ZnCl}_{2}(\mathbf{1})\right\}_{6} \mathrm{C}_{60}\right]^{\cdot} 3 \mathrm{MeOH}^{\cdot} 16 \mathrm{H}_{2} \mathrm{O}$ are compared in Table 2 . In all structures, the barrel-like molecules stack to form tubes that follow the $c$-axis, and we have discussed this in detail for a series of related structures. ${ }^{14}$ The cell parameters for $\left[\left\{\mathrm{ZnCl}_{2}(\mathbf{1})\right\}_{6}\right]-\mathrm{A}$ are similar to those of the host-guest complex $\left[2\left\{\mathrm{ZnCl}_{2}(\mathbf{1})\right\}_{6} \mathrm{C}_{60}\right]^{\cdot} 3 \mathrm{MeOH} \cdot 16 \mathrm{H}_{2} \mathrm{O}^{14}$ (Table 2). We have already discussed the doubling of the unit cell along the $c$-axis (the direction in which the tubes of stacked metallohexacycles run) on moving from $\left[\left\{\mathrm{ZnBr}_{2}(\mathbf{1})\right\}_{6}\right] \cdot 3 \mathrm{CHCl}_{3} \cdot 15 \mathrm{H}_{2} \mathrm{O}$ and related hexamers to $\left[2\left\{\mathrm{ZnCl}_{2}(\mathbf{1})\right\}_{6} \mathrm{C}_{60}\right]^{\cdot} 3 \mathrm{MeOH}^{\cdot} 16 \mathrm{H}_{2} \mathrm{O}$, as every second host molecule in a tube is occupied by a fullerene. ${ }^{14}$ Thus, we initially took the elongated unit cell in $\left[\left\{\mathrm{ZnCl}_{2}(\mathbf{1})\right\}_{6}\right]-$ A to be a signal that the tubes of stacked hexacycles hosted anthracene in a similar manner to the host-guest interactions in $\left[2\left\{\mathrm{ZnCl}_{2}(\mathbf{1})\right\}_{6} \mathrm{C}_{60}\right]$. However, as the earlier discussion reveals, this is not the case.

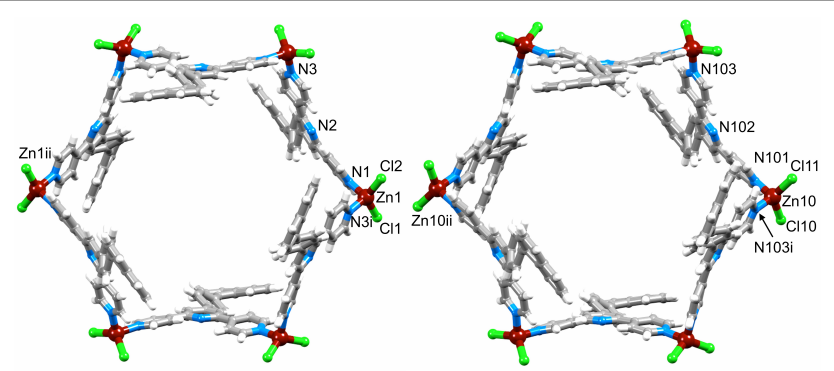

(a)

(b)

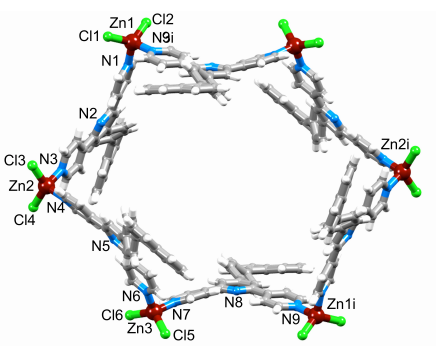

(c)

Fig. 1 Structures (looking down the c-axis) of (a) $\left[\left\{\mathrm{ZnCl}_{2}(\mathbf{1})\right\}_{6}\right]-\mathrm{A}$ (symmetry codes i $=-1 / 3+y, 1 / 3-x+y, 1 / 3-z ;$ ii $=2 / 3-x, 4 / 3-y, 1 / 3-z)$, (b) one of two independent molecules of $\left[\left\{\mathrm{ZnCl}_{2}(\mathbf{1})\right\}_{6}\right]-\mathrm{P}$ symmetry codes $\mathrm{i}=2 /{ }_{3}+x-y, 1 /{ }_{3}+x, 1 /{ }_{3}-z, \mathrm{ii}=2 /{ }_{3}-x,{ }^{4} /{ }_{3}-$ $y, 1 /{ }_{3}-z$ ), and (c) the second independent molecule of $\left[\left\{\mathrm{ZnCl}_{2}(\mathbf{1})\right\}_{6}\right]-\mathrm{P}$ (symmetry code $\mathrm{i}=1 / 3-x, 2 / 3-y, 5 / 3-z)$.

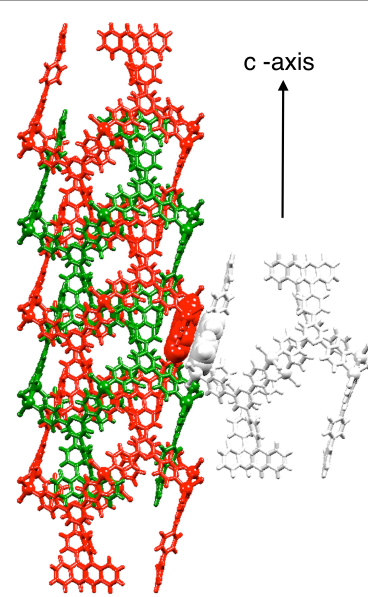

(a)

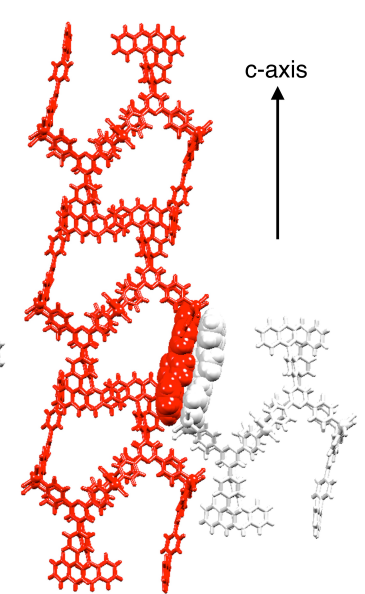

(b)

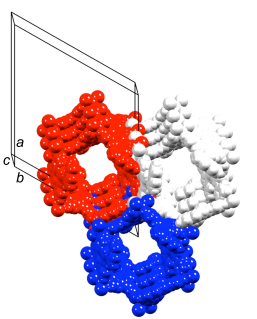

(c)

Fig. 2 (a) In $\left[\left\{\mathrm{ZnBr}_{2}(\mathbf{1})\right\}_{6}\right] \cdot 3 \mathrm{CHCl}_{3} \cdot 15 \mathrm{H}_{2} \mathrm{O},{ }^{14}$ red and green (crystallographically identical) hexacycles engage in efficient face-to-face stacking of naphthyl and pyridine domains within a tube; between tubes (green and grey) there are faceto-face pyridine/phenyl interactions. (b) Tube-assembly in $\left[\left\{\mathrm{ZnCl}_{2}(\mathbf{1})\right\}_{6}\right]-\mathrm{A}$, hexacycles and face-to-face interactions between columns which involves tpy$\mathrm{C}_{6} \mathrm{H}_{4}$-naphthyl $\pi$-stacking. (c) View down the c-axis in $\left[\left\{\mathrm{ZnCl}_{2}(\mathbf{1})\right\}_{6}\right]-\mathrm{A}$ to emphasize intermeshing of macrocycles. 
Table 2. Summary of cell dimensions for $\left[\left\{\mathrm{ZnCl}_{2}(\mathbf{1})\right\}_{6}\right]-\mathrm{A}$ and $\left[\left\{\mathrm{ZnCl}_{2}(\mathbf{1})\right\}_{6}\right]-$ $\mathrm{P}$, and comparison with those of $\left[\left\{\mathrm{ZnBr}_{2}(\mathbf{1})\right\}_{6}\right]^{\cdot} 3 \mathrm{CHCl}_{3} \cdot 15 \mathrm{H}_{2} \mathrm{O}^{14}$ and $\left[2\left\{\mathrm{ZnCl}_{2}(\mathbf{1})\right\}_{6} \mathrm{C}_{60}\right] \cdot 3 \mathrm{MeOH} \cdot 16 \mathrm{H}_{2} \mathrm{O} .{ }^{14}$

\begin{tabular}{|c|c|c|}
\hline Compound & $a=b / \AA$ & $c / \AA$ \\
\hline$\left[\left\{\mathrm{ZnCl}_{2}(\mathbf{1})\right\}_{6}\right]-\mathrm{A}$ & $35.744(2)$ & $23.9081(16)$ \\
\hline$\left[\left\{\mathrm{ZnCl}_{2}(\mathbf{1})\right\}_{6}\right]-\mathrm{P}$ & $70.6015(18)$ & $23.9920(6)$ \\
\hline$\left[\left\{\mathrm{ZnBr}_{2}(\mathbf{1})\right\}_{6}\right] \cdot 3 \mathrm{CHCl}_{3} \cdot 15 \mathrm{H}_{2} \mathrm{O}$ & $38.975(2)$ & $11.4827(8)$ \\
\hline$\left[2\left\{\mathrm{ZnCl}_{2}(\mathbf{1})\right\}_{6} \mathrm{C}_{60}\right] \cdot 3 \mathrm{MeOH} \cdot 16 \mathrm{H}_{2} \mathrm{O}$ & $38.4322(16)$ & $22.5450(10)$ \\
\hline
\end{tabular}

A comparison of the packing of $\left[\left\{\mathrm{ZnX}_{2}(\mathbf{1})\right\}_{6}\right]$ into tubes in $\left[\left\{\mathrm{ZnCl}_{2}(\mathbf{1})\right\}_{6}\right]-\mathrm{A}$ versus $\left[\left\{\mathrm{ZnBr}_{2}(\mathbf{1})\right\}_{6}\right] \cdot 3 \mathrm{CHCl}_{3} \cdot 15 \mathrm{H}_{2} \mathrm{O}$ reveals differences which rationalize the $c$-axis doubling. As previously discussed, ${ }^{14}$ when crystals are grown from mixtures of $1 / \mathrm{CHCl}_{3}$ layered with $\mathrm{ZnBr}_{2} / \mathrm{MeOH}$, the resulting $\left[\left\{\mathrm{ZnBr}_{2}(\mathbf{1})\right\}_{6}\right]$ metallohexacycles pack as shown in Fig. 4a. Analogous packing is seen in a series of complexes where $\mathrm{CHCl}_{3}$ and $\mathrm{MeOH}$ are used as solvents and has been described in detail. ${ }^{14}$ Two features are relevant to the present work: (i) the interdigitation of hexacycles within a tube, and (ii) inter-tube interactions involving face-to-face $\pi$-stacking of pyridine and phenyl rings. Note that the naphthyl domains are directed into the tube and are not involved in interactions between adjacent tubes in $\left[\left\{\mathrm{ZnBr}_{2}(\mathbf{1})\right\}_{6}\right] \cdot 3 \mathrm{CHCl}_{3} \cdot 15 \mathrm{H}_{2} \mathrm{O}$ (Fig. 2a). In contrast, crystals of $\left[\left\{\mathrm{ZnCl}_{2}(\mathbf{1})\right\}_{6}\right]-\mathrm{A}$ grown from layered 1/1,2dichlorobenzene and $\mathrm{ZnCl}_{2} / \mathrm{MeOH}$ mixtures with an intermediate anthracene/1,2-dichlorobenzene layer consist of tubular assemblies of cyclic $\left[\left\{\mathrm{ZnCl}_{2}(\mathbf{1})\right\}_{6}\right]$ molecules which map onto only half of the assembly in $\left[\left\{\mathrm{ZnBr}_{2}(\mathbf{1})\right\}_{6}\right] \cdot 3 \mathrm{CHCl}_{3} \cdot 15 \mathrm{H}_{2} \mathrm{O}$ (red molecules in Fig. $2 \mathrm{~b}$ versus 2a). Analysis of residual electron density in $\left[\left\{\mathrm{ZnCl}_{2}(\mathbf{1})\right\}_{6}\right]-\mathrm{A}$ provided no evidence for a second set of metallohexacycles. The distinction between the two structures is associated with inter-tube interactions. Maintaining the red molecules in Fig. 2a and $2 b$ as a reference point, a comparison shows that the grey hexacycle is translated along the $c$-axis on going from $\left[\left\{\mathrm{ZnBr}_{2}(\mathbf{1})\right\}_{6}\right] \cdot 3 \mathrm{CHCl}_{3} \cdot 15 \mathrm{H}_{2} \mathrm{O}$ to $\left[\left\{\mathrm{ZnCl}_{2}(\mathbf{1})\right\}_{6}\right]-\mathrm{A}$. Fig. $2 \mathrm{~b}$ shows the face-to-face interactions between a centrosymmetric pair of tpy- $\mathrm{C}_{6} \mathrm{H}_{4}$-naphthyl domains in adjacent columns. These interactions replace the naphthyl intra-tube contacts found in previous examples of this family of complexes. ${ }^{14}$ Fig. 2c illustrates that the tubular assemblies in $\left[\left\{\mathrm{ZnCl}_{2}(\mathbf{1})\right\}_{6}\right]-\mathrm{A}$ intermesh with one another. The differing role of the naphthyl domains in $\left[\left\{\mathrm{ZnBr}_{2}(\mathbf{1})\right\}_{6}\right] \cdot 3 \mathrm{CHCl}_{3} \cdot 15 \mathrm{H}_{2} \mathrm{O}$ and $\left[\left\{\mathrm{ZnCl}_{2}(\mathbf{1})\right\}_{6}\right]-\mathrm{A}$ leads to subtle differences in the lattice. The naphthyl units are oriented similarly with respect to the $c$-axis (compare the red molecules in Fig. 2a/2b). However, it is clear from Fig. 3 that the tight nesting of the metallomacrocycles in $\left[\left\{\mathrm{ZnBr}_{2}(\mathbf{1})\right\}_{6}\right] \cdot 3 \mathrm{CHCl}_{3} \cdot 15 \mathrm{H}_{2} \mathrm{O}$ results in a narrower axial cavity than in $\left[\left\{\mathrm{ZnCl}_{2}(\mathbf{1})\right\}_{6}\right]-\mathrm{A}$. In practice, these cavities are occupied by solvent molecules: $\left[\left\{\mathrm{ZnCl}_{2}(\mathbf{1})\right\}_{6}\right]-\mathrm{A}=$ $\left[\left\{\mathrm{ZnCl}_{2}(1)\right\}_{6}\right] \cdot 3 \mathrm{C}_{6} \mathrm{H}_{4} \mathrm{Cl}_{2} \cdot 6 \mathrm{MeOH}$. It is noteworthy that the SQUEEZED lattice of $\left[\left\{\mathrm{ZnCl}_{2}(\mathbf{1})\right\}_{6}\right]$-A is significantly more porous that that of the metallohexacycles earlier reported. Fig. $3 \mathrm{c}$ shows the channels that run parallel to the $a$-axis; symmetry requires that a similar set of channels follows the $b$-axis.

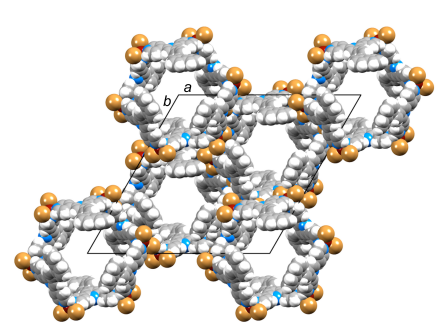

(a)

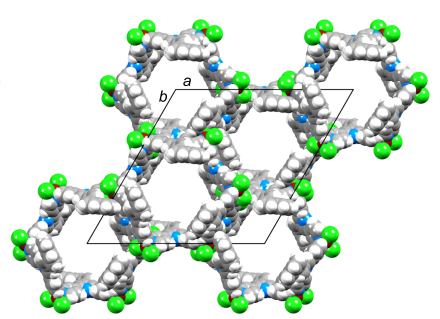

(b)

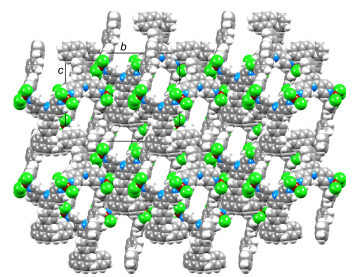

(c)

Fig. 3 Views down the $c$-axis highlighting the difference in void space within the tubular arrays in (a) $\left[\left\{\mathrm{ZnBr}_{2}(\mathbf{1})\right\}_{6}\right] \cdot 3 \mathrm{CHCl}_{3} \cdot 15 \mathrm{H}_{2} \mathrm{O},{ }^{14}$ and (b) $\left[\left\{\mathrm{ZnCl}_{2}(\mathbf{1})\right\}_{6}\right]-\mathrm{A}$. (c) Channels run parallel to the $a$-axis in $\left[\left\{\mathrm{ZnCl}_{2}(\mathbf{1})\right\}_{6}\right]-\mathrm{A}$.

The structure of $\left[\left\{\mathrm{ZnCl}_{2}(\mathbf{1})\right\}_{6}\right]-\mathrm{P}$ (perylene-derived assembly) bears similarities to that of $\left[\left\{\mathrm{ZnCl}_{2}(\mathbf{1})\right\}_{6}\right]-\mathrm{A}$, but differs in containing two crystallographically independent $\left[\left\{\mathrm{ZnCl}_{2}(\mathbf{1})\right\}_{6}\right]$ units (see Fig. 1 and Table 1). The lattice consists of tubular arrays (parallel to the $c$-axis), each consisting of one or other of the two independent molecules resulting in a $3: 1$ ratio of crystallographically distinct tubes (Fig. 4a). The columns interact through centrosymmetric pairings of tpy$\mathrm{C}_{6} \mathrm{H}_{4}$-naphthyl domains (Fig. 4b) which similar to those in $\left[\left\{\mathrm{ZnCl}_{2}(\mathbf{1})\right\}_{6}\right]$-A. Views of the lattice of $\left[\left\{\mathrm{ZnCl}_{2}(\mathbf{1})\right\}_{6}\right]-\mathrm{P}$ down the $a$ - or $b$-axes reveal infinite channels, analogous to those shown in Fig. $3 \mathrm{c}$ for $\left[\left\{\mathrm{ZnCl}_{2}(\mathbf{1})\right\}_{6}\right]-\mathrm{A}$. The porous nature of $\left[\left\{\mathrm{ZnCl}_{2}(\mathbf{1})\right\}_{6}\right]-\mathrm{A}$ and $\left[\left\{\mathrm{ZnCl}_{2}(\mathbf{1})\right\}_{6}\right]-\mathrm{P}$ is consistent with the problematic solvent loss that we encounter.

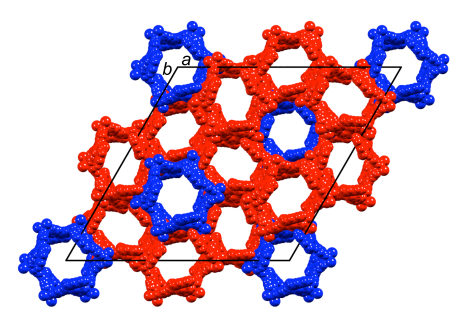

(a)

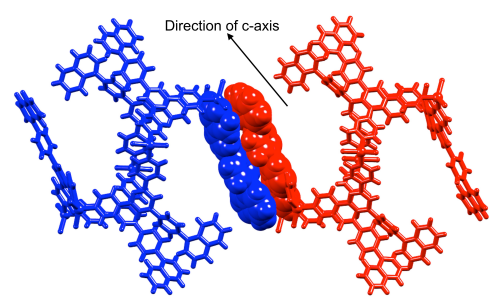

(b)

Fig. 4 (a) Packing of columns of metallohexacycles in $\left[\left\{\mathrm{ZnCl}_{2}(\mathbf{1})\right\}_{6}\right]-\mathrm{P}$ with a $3: 1$ ratio of independent molecules. Blue corresponds to Fig. $1 \mathrm{~b}$ and red to Fig. 1c. (b) Head-to-tail face-to-face $\pi$-stacking of tpy- $\mathrm{C}_{6} \mathrm{H}_{4}$-naphthyl domains 


\section{Reaction of 1 or 2 with $\mathrm{ZnCl}_{2}$ in the presence of pyrene}

In an extension of the study described above, a $\mathrm{ZnCl}_{2} / \mathrm{MeOH}$ solution was layered over 1/1,2-dichlorobenzene/MeOH separated by pyrene/1,2-dichlorobenzene. The product crystallized in the space group $P-1$ and proved to be the onedimensional coordination polymer $\left[\mathrm{ZnCl}_{2}(\mathbf{1})\right]_{n}$ with an unexpected crenellated topology (Fig. 5). Disordered solvent necessitated the use of SQUEEZE ${ }^{19}$ to treat the reflection data. The asymmetric unit (Fig. S3 $\uparrow$ ) contains four $\left\{\mathrm{ZnCl}_{2}(\mathbf{1})\right\}$ units which define an up/up/up/down arrangement of the 4'-(4(naphth-1-yl)phenyl) domains along the chain. Each $\mathrm{Zn}(\mathrm{II})$ centre is in a distorted tetrahedral environment. Bond lengths are unexceptional (caption to Fig. $\mathrm{S} 3 \dagger$ ), and the $\mathrm{N}-\mathrm{Zn}-\mathrm{N}$ bond angles for the four independent $\mathrm{Zn}$ atoms lie in the range $97.37(14)$ to $104.45(13)^{\circ}$. The $4,2^{\prime}: 6^{\prime}, 4^{\prime \prime}$-tpy domains vary in their deviation from planarity, with angles between the planes of bonded pyridine rings ranging from 5.4 to $27.5^{\circ}$. Along a chain, the ligand-bridged $\mathrm{Zn}$...Zn separations are 12.863(2), $12.400(1)$ and $12.325(2) \AA$ compared to the unbridged $\mathrm{Zn} 2 \ldots \mathrm{Zn} 1^{\mathrm{i}}$ distance of $14.130(2) \AA$ (symmetry code $\mathrm{i}=x, y$, $1+z)$. Centrosymmetric pairs of chains associate through $\pi$ stacking of pairs of pyridine rings of 4,2':6',4"-tpy domains (distance between the least squares planes through the rings containing N2a/N3a and $\mathrm{N} 2 \mathrm{a}^{\mathrm{i}} / \mathrm{N} 3 \mathrm{a}^{\mathrm{i}}=3.41 \AA$; symmetry code $\mathrm{i}$ $=4-x, 1-y, 2-z$ ) as shown in Fig. 6 .

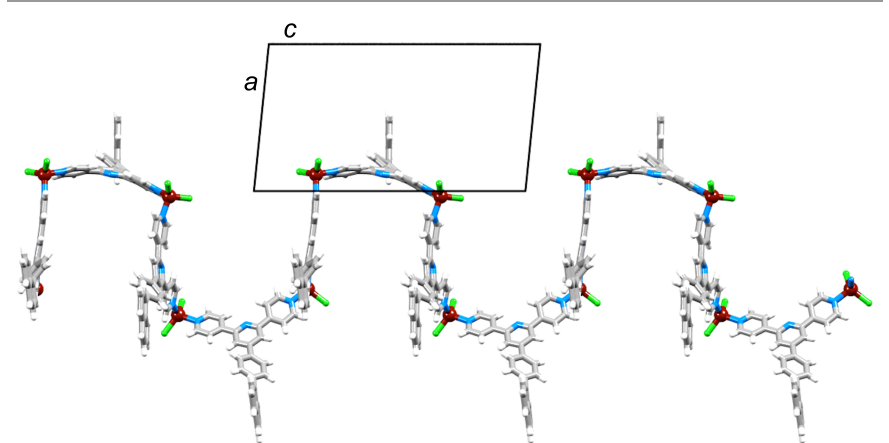

Fig. 5 Part of one polymer chain in $\left[\mathrm{ZnCl}_{2}(\mathbf{1})\right]_{n}$. See Fig. S3+ for atom numbering.

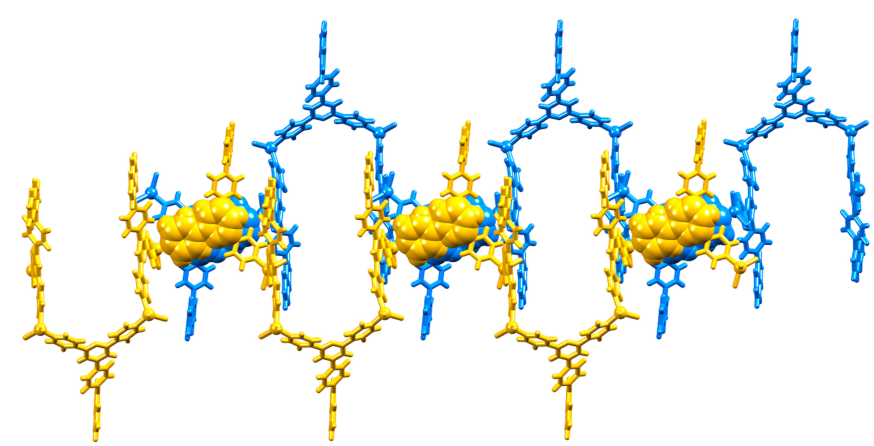

Fig. $6 \pi$-Interactions between $4,2^{\prime}: 6^{\prime}, 4^{\prime \prime}$-tpy domains of centrosymmetric pairs of chains in $\left[\mathrm{ZnCl}_{2}(\mathbf{1})\right]_{n}$.

The crenellated-chain structure observed in $\left[\mathrm{ZnCl}_{2}(\mathbf{1})\right]_{n}$ is also found in $\left[\mathrm{ZnCl}_{2}(\mathbf{2})\right]_{n}$, crystals of which were grown in the presence of pyrene in an analogous manner to those of
$\left[\mathrm{ZnCl}_{2}(\mathbf{1})\right]_{n}$. The asymmetric unit (in space group $P-1$ ) of $\left[\mathrm{ZnCl}_{2}(\mathbf{2})\right]_{n}$ contains four independent tetrahedral zinc atoms (Fig. S4†). Bond distances are given in the caption to Fig. S4†, and are typical. The $\mathrm{N}-\mathrm{Zn}-\mathrm{N}$ bond angles are in the range 94.25(16) to $104.56(14)^{\circ}$, comparable with those in $\left[\mathrm{ZnCl}_{2}(\mathbf{1})\right]_{n}$. Each ligand 2 bridges two $\mathrm{ZnCl}_{2}$ units, generating a onedimensional chain that runs parallel to the $c$-axis. The three bridged $\mathrm{Zn}$...Zn distances in the asymmetric unit of $\left[\mathrm{ZnCl}_{2}(\mathbf{2})\right]_{n}$ are 12.3425(9), 13.062(1) and 12.4525(9) $\AA$; the unbridged $\mathrm{Zn}$...Zn distance is 13.420 (1) $\AA$, which is shorter than the comparable separation in $\left[\mathrm{ZnCl}_{2}(\mathbf{1})\right]_{n}$. Although the general features of each chain are similar in $\left[\mathrm{ZnCl}_{2}(\mathbf{1})\right]_{n}$ and $\left[\mathrm{ZnCl}_{2}(\mathbf{2})\right]_{n}$, the interactions between the chains are different. The face-to-face $\pi$-interactions shown in Fig. 6 for $\left[\mathrm{ZnCl}_{2}(\mathbf{1})\right]_{n}$ are replaced by $\pi$-interactions between $4^{\prime}$-phenyl-4,2':6',4"-tpy domains in $\left[\mathrm{ZnCl}_{2}(2)\right]_{n}$ (Fig. 7). The pyridine rings containing $\mathrm{N} 2 \mathrm{~d}$ and $\mathrm{N}_{2} \mathrm{~d}^{\mathrm{i}}$ (symmetry code $\mathrm{i}=1-x, 1-y, 1-z$ ) are slipped (centroid separation $=4.6 \AA$ ) and their planes are separated by $3.65 \AA$. In contrast, the associated pyridine...phenyl $\pi$ interaction is less efficient because the planes of the rings subtend an angle of $21.2^{\circ}$. The difference is highlighted in Fig. 8 which presents views down the $c$-axis in each structure.

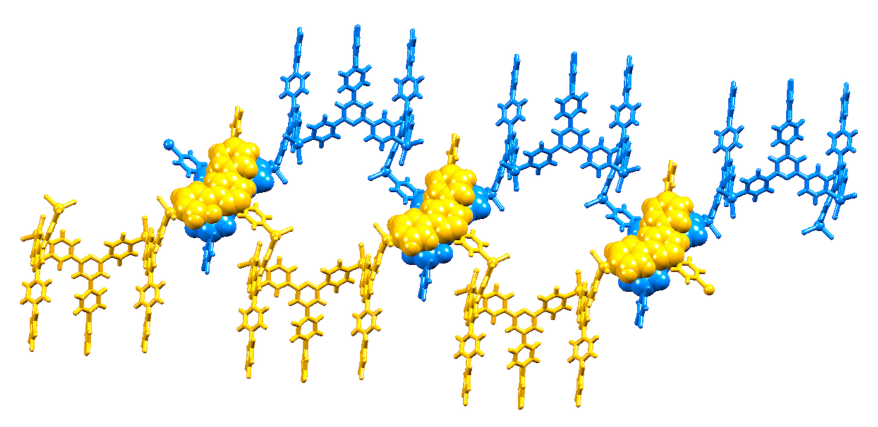

Fig. $7 \pi$-Interactions between $4^{\prime}$-phenyl-4,2':6',4"-tpy domains of centrosymmetric pairs of chains in $\left[\mathrm{ZnCl}_{2}(2)\right]_{n}$.

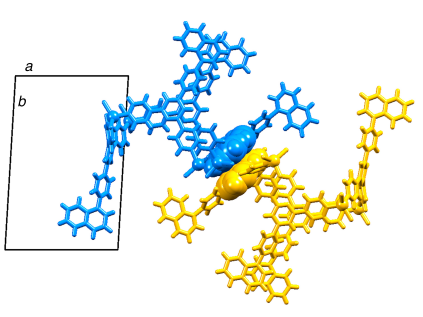

(a)

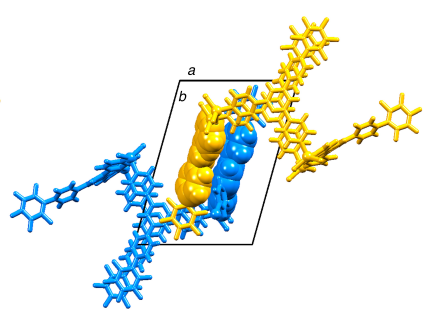

(b)
Fig. 8. $\pi$-Interactions between centrosymmetric pairs of chains in (a) $\left[\mathrm{ZnCl}_{2}(\mathbf{1})\right]_{n}$ and (b) $\left[\mathrm{ZnCl}_{2}(2)\right]_{n}$, viewed along the $c$-axis.

Each of the one-dimensional coordination polymers in $\left[\mathrm{ZnCl}_{2}(\mathbf{1})\right]_{n}$ and $\left[\mathrm{ZnCl}_{2}(\mathbf{2})\right]_{n}$ contains repeat units that resemble three sides of a square box (Fig. 5). This is particularly true in $\left[\mathrm{ZnCl}_{2}(2)\right]_{n}$ where the unbridged $\mathrm{Zn}$...Zn separation $(13.420(1)$ $\AA$ ) is close to the bridged separation on the opposite side of the 'square' (13.062(1) $\AA$ ). The partial refinements of the latter two structures without the use of SQUEEZE allowed us to verify 
the presence of 1,2-dichorobenzene and pyrene molecules in the lattice, but these structures were not of publishable quality.

The colourless plates in the crystallization tube of $\left[\mathrm{ZnCl}_{2}(2)\right]_{n}$ were found to be of two crystallographically different types, the second crystallizing in the tetragonal space group $P \overline{4} 2_{1} c$. In contrast to the triclinic coordination polymer, $\mathrm{X}$-ray diffraction revealed the second set of crystals to be the discrete metallosquare $\left[\left\{\mathrm{ZnCl}_{2}(\mathbf{2})\right\}_{4}\right]$ (Fig. 9a). Although the structure quality is low, the gross features of the molecule are unambiguously defined. The asymmetric unit contains one $\left\{\mathrm{ZnCl}_{2}(2)\right\}$ entity and the molecule displays $\overline{4}$ symmetry; it follows that the $4^{\prime}-\left(2^{\prime}, 3^{\prime}, 4^{\prime}, 5^{\prime}, 6^{\prime}-\right.$-pentafluorobiphenyl-4-yl) substituents are in an up/down/up/down arrangement around the ring. The four $\mathrm{Zn}$ atoms are near coplanar (deviation from least squares plane $=0.01 \AA$ ); although $\mathrm{Zn} 1$ lies on a general position, its $z$ coordinate is close to 0 and generation of the remaining three positions by $\overline{4}$ symmetry results in the planar array. The ligand-bridged $\mathrm{Zn}$...Zn separation is $12.725(1) \AA$, compared to a range of $12.3425(9)$ to $13.062(1) \AA$ in the polymer $\left[\mathrm{ZnCl}_{2}(\mathbf{2})\right]_{n}$. The conformation of the $\left[\left\{\mathrm{ZnCl}_{2}(\mathbf{2})\right\}_{4}\right]$ molecule is reminiscent of the 1,3-alternate form of a calix[4]arene or cyclophane (Scheme 2). For example, the tetrapyridinocyclophane ${ }^{20}$ (Scheme 2 ) crystallizes in the space group $P \overline{4} 2{ }_{1} c$ with columns of interdigitated molecules running parallel to the $c$-axis $\left(\mathrm{CSD}^{21}\right.$ refcode QEGGOY). An analogous assembly is observed for molecules of $\left[\mathrm{ZnCl}_{2}(\mathbf{2})\right]_{n}$. Fig. $9 \mathrm{~b}$ shows the the H...F contacts $(2.27,2.40$ and $2.55 \AA$ ) that support the interdigitation of adjacent molecules. This leads to the assembly of tubes that follow the $c$-axis. The space-filling respresenation in Fig. 10a illustrates the tight intermeshing of adjacent molecules in the tubular array. Fig. 10b illustrates the packing of tubes in the lattice. There are no $\pi$-stacking interactions either within a tube nor between adjacent tubes. The intra- and inter-tube cavities that follow the $c$-axis are filled with solvent molecules but their disorder prevented further insight into the role of guest molecules in the structure.

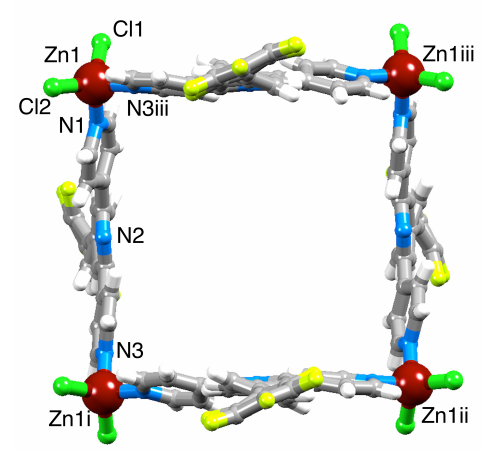

(a)

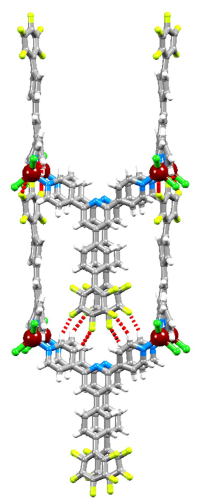

(b)
Fig. 9 (a) Structure of $\left[\left\{\mathrm{ZnCl}_{2}(2)\right\}_{4}\right]$. Selected bond parameters: $\mathrm{Zn} 1-\mathrm{N} 3^{\mathrm{iii}}=$ 2.003(5), $\mathrm{Zn} 1-\mathrm{N} 1=2.036(5), \mathrm{Zn} 1-\mathrm{Cl} 2=2.219(2), \mathrm{Zn} 1-\mathrm{Cl} 1=2.2200(19) \AA ̊ ㄱ$ N3 ${ }^{\mathrm{iii}}-$ $\mathrm{Zn} 1-\mathrm{N} 1=104.9(2), \mathrm{N} 3^{\mathrm{iii}}-\mathrm{Zn} 1-\mathrm{Cl} 2105.58(14), \mathrm{N} 1-\mathrm{Zn} 1-\mathrm{Cl} 2=110.12(17), \mathrm{N} 3^{\mathrm{iii}}-$ $\mathrm{Zn} 1-\mathrm{Cl} 1$ 107.28(16), N1-Zn1-Cl1 103.52(16), $\mathrm{Cl} 2-\mathrm{Zn} 1-\mathrm{Cl} 1=124.04(9)^{\circ}$. Symmetry codes: $\mathrm{i}=y, 1-x, 2-z ; \mathrm{ii}=1-x, 1-y, z ; \mathrm{iii}=1-y, x, 2-z$. (b) Interdigitation of adjacent $\left[\left\{\mathrm{ZnCl}_{2}(2)\right\}_{4}\right]$ with $\mathrm{H}$...F interactions shown in red hashed lines.

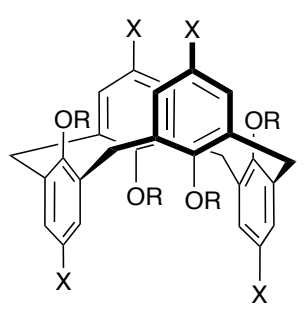

Calix[4]arene

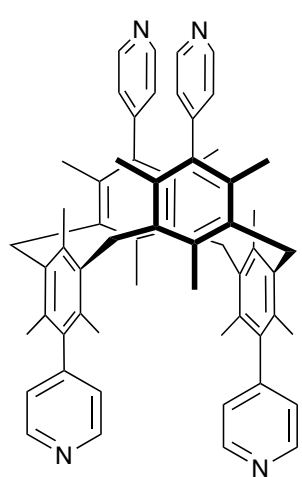

Tetrapyridinocyclophane
Scheme 2. Examples, in the 1,3-alternate conformation, of structural analogues of $\left[\left\{\mathrm{ZnCl}_{2}(2)\right\}_{4}\right]$.

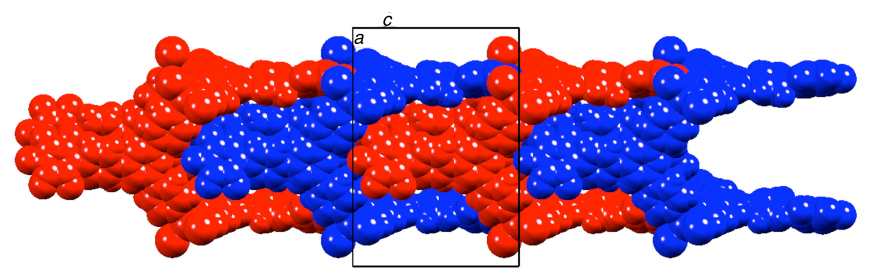

(a)

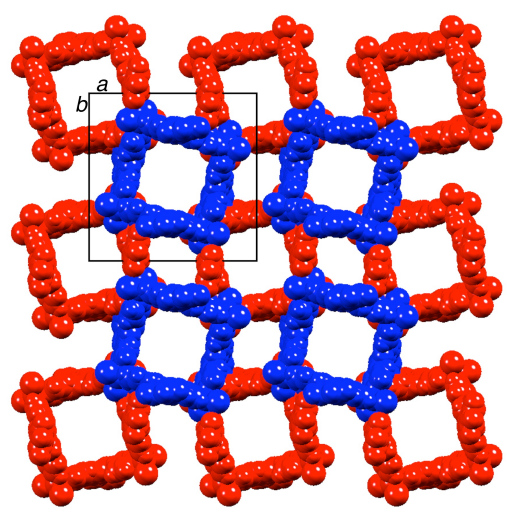

(b)

Fig. 10 Packing of metallosquares in $\left[\left\{\mathrm{ZnCl}_{2}(2)\right\}_{4}\right]$. (a) Intermeshing of molecules (all crystallographically equivalent) in part of one tube. (b) View down the tube axes.

\section{From $\mathrm{ZnCl}_{2}$ to $\mathrm{ZnI}_{2}$}

The structural diversity observed when $\mathrm{ZnCl}_{2}$ reacts with $\mathbf{1}, \mathbf{2}$ or 3 appears to be a matter of environmental control. Layering of ligand/ $\mathrm{CHCl}_{3}$ and $\mathrm{ZnCl}_{2} / \mathrm{MeOH}$ solutions ${ }^{14}$ seems to favour the assembly of metallohexacycles. The introduction of 1,2dichlorobenzene as solvent and the addition of polycyclic aromatic potential guests leads to greater structural diversity including the metallosquare (Fig. 11) which is clearly related structurally to the crenellated polymers (Figs. 5-7). We have shown that replacement of $\mathrm{ZnCl}_{2}$ by $\mathrm{ZnBr}_{2}$ in the ligand/ $\mathrm{CHCl}_{3}$ and $\mathrm{ZnCl}_{2} / \mathrm{MeOH}$ reactions leads to analogous products. ${ }^{14}$ In an extension of this work, we investigated the reaction of $\mathrm{ZnI}_{2}$ with ligand 1. Layering of $\mathbf{1} / \mathrm{CHCl}_{3}$ and $\mathrm{ZnI}_{2} / \mathrm{MeOH}$ solutions at room temperature yielded crystals of the one-dimensional 
coordination polymer $\left[2\left\{\mathrm{ZnI}_{2}(\mathbf{1})\right\} \mathrm{CHCl}_{3}\right]_{n}$. The complex crystallizes in the monoclinic space group $P 2_{1} / c$ with two independent $\left\{\mathrm{ZnI}_{2}(\mathbf{1})\right\}$ units in the asymmetric unit (Fig. S5 $\dagger$ ). The $\mathrm{Zn}$ coordination environment is distorted tetrahedral, and bond distances are unexceptional. Each ligand 1 bridges two $\mathrm{Zn}$ atoms and the central $\mathrm{N}$ atom $(\mathrm{N} 2 \mathrm{a}$ or $\mathrm{N} 2 \mathrm{~b})$ remains uncoordinated. The two independent $\mathrm{I}-\mathrm{Zn}-\mathrm{I}$ bond angles are 117.97(3) and $116.80(4)^{\circ}$ compared to $\mathrm{N}-\mathrm{Zn}-\mathrm{N}$ angles of 101.3(2) and $102.3(2)^{\circ}$. Each of the two independent polymer chains is built by a glide plane and is similar to those observed for $\left[\mathrm{ZnY}_{2}\left(4^{\prime}-\left(4-(3-\text { chloropyridyl))-4,2':6',4"-tpy) }]_{n}(\mathrm{Y}=\mathrm{Cl}\right.\right.\right.$ or I) ${ }^{13}$ and $\left[\mathrm{ZnI}_{2} \text { (4'-(4-pyridyl)-4,2':6',4"-tpy) }\right]_{n}{ }^{5}$ As a consequence of this symmetry operation, the 4'-(4-(naphth-1-yl)phenyl) substituents all lie on the same side of the chain (Fig. 11). The ligand-bridged $\mathrm{Zn}$...Zn separations for the two chains are similar (12.258(1) and 12.433(1) A). Chains A associate with one another through head-to-tail pairings of ligands $\mathbf{1}$ as shown in Fig. 12. However, the mutual twisting of the rings within the ligand results in less than optimum face-to-face $\pi$-stacking (angles between the planes of naphthyl/phenylene, phenylene/pyridine-N2, pyridines N3/N2 and pyridines N1/N2 $=48.5,57.6,65.2$ and $23.3^{\circ}$, respectively). The space-filling diagram in Fig. $12 \mathrm{~b}$ shows that the resulting assembly is a corrugated sheet propagating in the $b c$-plane. An analogous packing arrangement is observed for chains $\mathrm{B}$, leading to two crystallographically independent, intermeshed corrugated sheets (brown and orange in Fig. 13).

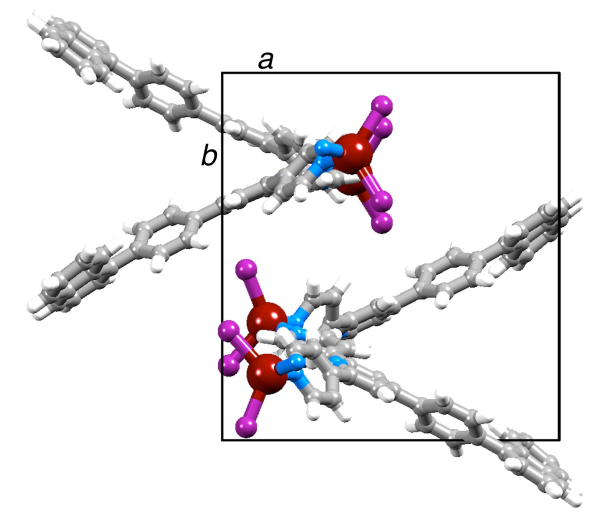

Fig. 11 View down the $c$-axis in $\left[2\left\{\mathrm{ZnI}_{2}(\mathbf{1})\right\} \mathrm{CHCl}_{3}\right]_{n}$ showing the two independent coordination polymer chains (chain $A$, top; chain $B$, bottom); solvent molecules are omitted.

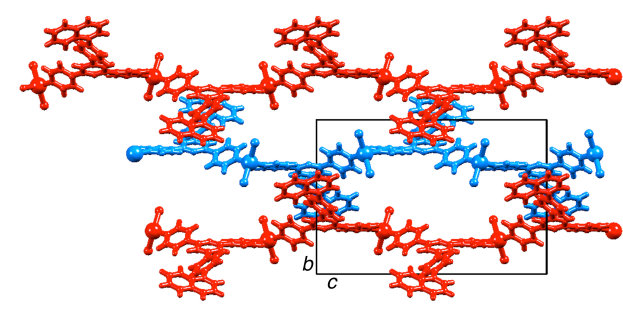

(a)

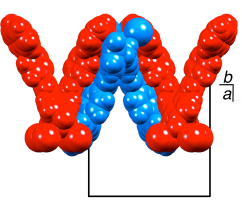

(b)
Fig. 12 (a) Alternate ligands in independent chains $\mathrm{A}$ in $\left[2\left\{\mathrm{ZnI}_{2}(\mathbf{1})\right\} \mathrm{CHCl}_{3}\right]_{n}$ stack with those of the next chain to form a corrugated sheet, part of which is shown in (b). Each coordination polymer chain follows the $c$-axis.

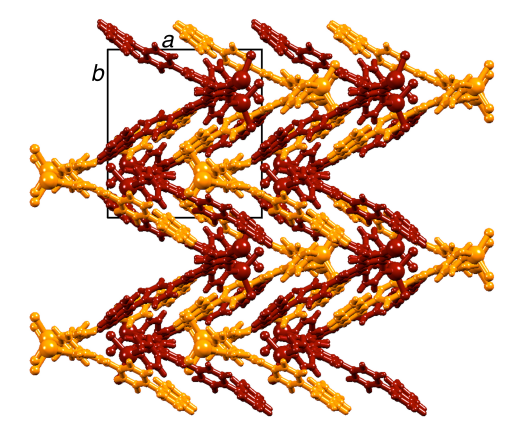

Fig. 13 Packing of crystallographically independent (brown and orange) corrugated sheets in $\left[2\left\{\mathrm{ZnI}_{2}(\mathbf{1})\right\} \mathrm{CHCl}_{3}\right]_{n}$; solvent molecules are omitted.

\section{Conclusions}

By using layering methods at room temperature, reaction of $\mathrm{ZnCl}_{2}$ (MeOH solution) with 1 (1,2-dichlorobenzene/MeOH solution) in the presence of either anthracene or perylene results in the assembly of discrete metallohexacycles $\left[\left\{\mathrm{ZnCl}_{2}(\mathbf{1})\right\}_{6}\right]$. At the molecular level, these are similar in the two complexes $\left[\left\{\mathrm{ZnCl}_{2}(\mathbf{1})\right\}_{6}\right]-\mathrm{A}$ and $\left[\left\{\mathrm{ZnCl}_{2}(\mathbf{1})\right\}_{6}\right]-\mathrm{P} ; \mathrm{A}$ and $\mathrm{P}$ signify the presence of anthracene or perylene, respectively. ${ }^{1} \mathrm{H}$ NMR spectroscopic data confirm that neither anthracene nor perylene are included as guest molecules in the structures and this is consistent with modelling of SQUEEZED electron density in the structures. The hexacycles stack into tubular arrays which are more open than those previously described for related complexes. ${ }^{14}$ In the presence of pyrene, a one-dimensional coordination polymer $\left[\mathrm{ZnCl}_{2}(\mathbf{1})\right]_{n}$ assembles; this exhibits a crenellated topology replicated in the polymer $\left[\mathrm{ZnCl}_{2}(2)\right]_{n}$. In the latter case, competitive formation of the discrete metallosquare $\left[\left\{\mathrm{ZnCl}_{2}(\mathbf{2})\right\}_{4}\right]$ is observed, the latter being structurally related to a unit in the crenellated chain. In both coordination polymers, pyrene is incorporated as a guest along with 1,2-dichlorobenzene (used as a solvent in the crystallizations). The structure of a one-dimensional polymer $\left[\mathrm{ZnI}_{2}(\mathbf{1})\right]_{n}$ has been determined; head-to-tail pairings of ligands between adjacent chains is the primary packing interaction and leads to the assembly of corrugated sheets.

\section{Acknowledgements}

We thank the Swiss National Science Foundation, the European Research Council (Advanced Grant 267816 LiLo) and the University of Basel for financial support.

\section{Notes and references}

${ }^{a}$ Department of Chemistry, University of Basel, Spitalstrasse 51, CH4056, Switzerland. email: catherine.housecroft@unibas.ch; FAX: +4161 267 1008 .

$\dagger$ Electronic Supplementary Information (ESI) available: Figs. S1 and S2: Comparison of the ${ }^{1} \mathrm{H}$ NMR spectra of $\mathrm{DMF}-\mathrm{d}_{7}$ solutions of anthracene, $\mathbf{1}$ and $\left[\left\{\mathrm{ZnCl}_{2}(\mathbf{1})\right\}_{6}\right]-\mathrm{A}$, and of perylene, 1 and $\left[\left\{\mathrm{ZnCl}_{2}(\mathbf{1})\right\}_{6}\right]-\mathrm{P}$; Fig. S3-S5: Asymmetric units of $\left[\mathrm{ZnCl}_{2}(\mathbf{1})\right]_{n}$ and $\left[\mathrm{ZnCl}_{2}(\mathbf{2})\right]_{n}$ and 
$\left[2\left\{\mathrm{ZnI}_{2}(\mathbf{1})\right\} \cdot \mathrm{CHCl}_{3}\right]_{n}$, with atom numbering and selected bond parameters. See DOI: $10.1039 / \mathrm{b} 000000 \mathrm{x} /$

1 C. E. Housecroft, Dalton Trans., 2014, doi 10.1039/C4DT00074A

2 F. Kröhnke, Synthesis, 1976, 1.

3 P. Yang, M.-S. Wang, J.-J. Shen, M.-X. Li, Z.-X. Wang, M. Shao and X. He, Dalton Trans., 2014, 43, 1460.

4 E. C. Constable, G. Zhang, C. E. Housecroft and J. A. Zampese, CrystEngComm, 2011, 13, 6864.

5 J. Heine, J. Schmedt auf der Günne and S. Dehnen, J. Am. Chem. Soc., 2011, 133, 10018.

6 F. Yuan, Q.-E. Zhu, H.-M. Hu, J. Xie, B. Xu, C.-M. Yuan, M.-L. Yang, F.-X. Dong and G.-L. Xue, Inorg. Chim. Acta, 2013, 397, 117.

7 H.-N. Zhang, F. Yuan, H.-M. Hu, S.-S. Shen and G.-L. Xue, Inorg. Chem. Comm., 2013, 34, 51.

8 Y.-L. Gai, F.-L. Jiang, L. Chen, Y. Bu, M.-Y. Wu, K. Zhou, J. Pan and M.-C. Hong, Daltons Trans., 2013, 42, 9954.

9 J. Song, B.-C. Wang, H.-M. Hu, L. Gou, Q.-R. Wu, X.-L. Yang, Y.Q. Shangguan, F.-X. Dong and G.-L. Xue, Inorg. Chim. Acta, 2011, 366, 134.

10 E. C. Constable, C. E. Housecroft, S. Vujovic and J. A. Zampese, CrystEngComm, 2014, advance article, DOI: 10.1039/C4CE00324A.

11 E. C. Constable, C. E. Housecroft, M. Neuburger, J. Schönle, S. Vujovic and J. A. Zampese. Polyhedron, 2013, 62, 260.

12 E. C. Constable, C. E. Housecroft, S. Vujovic, J. A. Zampese, A. Crochet and S. R. Batten, CrystEngComm, 2013, 15, 10068.

13 E. C. Constable, G. Zhang, C. E. Housecroft and J. A. Zampese, CrystEngComm, 2011, 13, 6864.

14 E. C. Constable, C. E. Housecroft, S. Vujovic and J. A. Zampese, CrystEngComm, 2014, 16, 328.

15 Bruker Analytical X-ray Systems, Inc., 2006, APEX2, version 2 User Manual, M86-E01078, Madison, WI.

16 G. M. Sheldrick, Acta Crystallogr., Sect. A, 2008, 64, 112.

17 I. J. Bruno, J. C. Cole, P. R. Edgington, M. K. Kessler, C. F. Macrae, P. McCabe, J. Pearson and R. Taylor, Acta Crystallogr., Sect. B, 2002, 58, 389.

18 C. F. Macrae, I. J. Bruno, J. A. Chisholm, P. R. Edgington, P. McCabe, E. Pidcock, L. Rodriguez-Monge, R. Taylor, J. van de Streek and P. A. Wood, J. Appl. Cryst., 2008, 41, 466.

19 A. L. Spek, Acta Crystallogr., Sect. D, 2009, 65, 148.

20 C. Klein, E. Graf, M. W. Hosseini and A. De Cian, New J. Chem., 2001, 25, 207.

21 F. H. Allen, Acta Crystallogr., Sect. B, 2002, 58, 380. 